\title{
シンポジウム趣旨，動物由来感染症を中心に
}

\author{
吉川泰弘 \\ 千葉科学大学危機管理学部 $=288-0025$ 千葉県銚子市潮見町 3 番地

\section{Trend of National and International Wildlife Disease Control}

\author{
Yasuhiro YOSHIKAWA \\ Department of Animal Risk Management, Faculty of Risk and Crisis Management, Chiba Institute of Science, \\ Shiomicho-3, Choshi-City, Chiba 288-0025, Japan
}

\begin{abstract}
The World Health Organization, Food and Agriculture Organization and UNICEF of the United Nations, Office International des Epizooties and World Bank etc. discussed on 21st century problems to bring together. As a result, the Wildlife Conservation Society declared the Manhattan Principle in 2004, as a general rule for overcoming the problems. "One World, One Health" is the keyword of this principle. This principle is at the basic concepts as follows. "Outbreak of West Nile fever, Ebola hemorrhagic fever, SARS, monkey pox, BSE and avian influenza epidemics in recent years suggested that human and animal health is closely related. Therefore, it needs an integrated approach pursuing human, livestock and wildlife health (One health). Such as extinction of species, degradation of habitat, pollution, invasion of exotic species and global warming are changing the primeval nature of the earth. Emerging and re-emerging infectious diseases pose a threat to humans (including food supply, the economic activity), but also affect biodiversity in supporting the base of the world. We live in the same world (One World). In order to overcome the infectious diseases of 21 st century, we need broader conservation of environment and interdisciplinary studies for disease prevention, surveillance, monitoring and management." Then, the WCS is offering a 12 -item action plan of concrete. We will discuss about the zoonosis derived from wildlife, interface in livestock and wildlife infections, and wildlife infection itself, in this symposium. We put coordination of human and veterinary medicine as the basis of infection control. Various international projects are progressing under the name, such as One Health Initiative, One World One Health, One Medicine, and Conservation Medicine. The basic concept is similar to but different names. In this symposium, we will present examples of research being pursued in order to realize these concepts in Japan. We will introduce the strategy of international organizations (OIE) and the studies of core research institute abroad. I would like to discuss the prospects of this subject in Japan.
\end{abstract}

Key words : zoonosis, Manhattan principle, One World, One Health, risk analysis, risk management

Jpn. J.Zoo. WildI. Med. 18(3) : 75-82, 2013

\section{1. 座長からの問題提起：ズーノーシスを中心に}

野生動物由来食品（ゲームミート）のリスクとその統御 方法に関する研究, 野生動物と家畜の間で行き来する感染症の 統御, 野生動物疾病統御に関連する海外の研究施設の動向およ び国際機関（OIE）の戦略などに関しては, 後の講演者が報告 してくれるので, ここでは野生動物由来感染症の統御に関する 国内外の動向を紹介し，主として，これまでの日本の対応およ びその課題と展望を述べる。

\section{2. ズーノーシスの特徵は ?}

人の感染症の病原体の約 60\%（868 種/1,415 種）は, 野
生動物を含め動物に由来する病原体である。また, 近年出現し た, 新興感染症の 3/4（約 75\%）は動物由来感染症（ズーノー シス）である。さらに, 動物由来感染症の病原体の約 $80 \%$ が, バイオテロに用いられる可能性があるといわれている。

このようなズーノーシスの特徴は, 容易にグローバル化しや すく, 繰り返し流行を起こすこと, 流行のメカニズムが不明で 制御が非常に難しいことである。その理由は，ズーノーシスの 病原体が主に野生動物に由来しているためである。したがって, その対応は, 人や家畜での流行のみを対象にするのではなく, 野生動物間での病原体の生態を明らかにし, グローバルな対策 を立てる必要がある。マンハッタン原則にいわれているように， 環境, 宿主, 病原体の生態系の解析というトップダウン方式 (新 
吉川泰弘

特徵

・近年の感染症の多くは動物由来感染症

・容易にグローバル化, 繰り返し流行

・真の原因が不明で制御困難

\section{理由と対応}

・主に野生動物に由来

・人や家畜を対象とした対策でなく，野生動 物と病原体の視点からの研究

・グローバルな対策

\section{戦略と戦術}

·環境, 宿主, 病原体の生態系の解析という, トップダウン方式

•フィールド科学と疫学, 生態学, 感染症学, リスク科学の統合的研究体制

\begin{tabular}{|c|c|}
\hline $2000 \mathrm{~s}$ & $\begin{array}{l}\text { Severe acute respiratory syndrome （SARS）：コウモリ } \\
\text { Swine flu （A/H1N1 pandemic）：ブタ }\end{array}$ \\
\hline 1990s & $\begin{array}{l}\text { Hendra virus infection：コウモリ，ウマ } \\
\text { Nipah virus infection：コウモリ，ブタ } \\
\text { Lyssa virus infection : コウモリ } \\
\text { Hanta virus pulmonary syndrome（HPS）：野生げっ歯類 } \\
\text { Highly pathogenic avian influenza（H5N1, H7N7）：野鳥 } \\
\text { vCJD (BSE）：ウシ }\end{array}$ \\
\hline 1980s & $\begin{array}{l}\text { AIDS : サル類 } \\
\text { Lyme disease : 野生げっ歯類他 } \\
\text { Hepatitis E : ブタ, シカ, イノシシ } \\
\text { Enterohemorrhagic E. coli (O-157) infection : ウシ }\end{array}$ \\
\hline $1970 \mathrm{~s}$ & $\begin{array}{l}\text { Ebola hemorrhagic fever：コウモリ，サル類 } \\
\text { Campylobacter infection：ニワトリ（食中毒） } \\
\text { Cryptosporidiosis：野生動物（水系感染） }\end{array}$ \\
\hline 1960s & $\begin{array}{l}\text { Lassa fever：マストミス（野生げっ歯類） } \\
\text { Marburg disease：コウモリ，サル類 }\end{array}$ \\
\hline
\end{tabular}

図 1 ズーノーシスの特徵（図左）と半世紀の事例（図右）

しいパラダイム) の導入, フィールド科学と疫学, 生態学, 感 染症学, リスク科学の統合的研究体制という, 従来の分野を超 えた融合研究の推進が必要である。

実際，主な新興感染症，1960 年代のマールブルグ病，ラッ サ熱, 70 年代のエボラ出血熱, キャンピロバクター症, クリ プトスポリジウム症, 80 年代のエイズ, ライム病, E 型肝炎, O-175, 90 年代のヘンドラウイルス感染症，二パウイルス感 染症, リッサウイルス感染症, ハンタウイルス肺症候群, 高病 原性鳥インフルエンザ，変異型 CJD， 2000 年代の SARS，パ ンデミック豚インフルエンザなどはいずれも動物由来感染症で ある（図 1）。

\section{3. 感染症とは?}

このような状況に鑑み，新しい発想法で，もう一度感染症と いうものを考えてみると, これまでと違ったものが見えてくる。 すなわち, 我々が病原体と呼んでいるもの, 細菌, ウイルス, 真菌，原虫や寄生虫は，地球上に初期に出現し，この世界を凌 駕してきた生物群である。そして, 現在もまだ, 生物圈のほと んどを占めている生物叢（fauna and flora）である。

他方, 宿主動物（家畜や人）は, 地球上に最後に出現した生 物群といえる。その意味では, 我々がこれまでに知っている感 染症は, 地球上に最初に現れた生物群と最後に現れた生物群の 相互作用といえる。

その意味では, 自然界の相互作用から見れば, 人と家畜の感 染症は特殊解に過ぎず，一般解は全て野生動物を含む野生生物 と病原体の相互作用の中にあるといえる。実際，ウイルスに寄 生するウイルス, 細菌に感染するウイルス, 原虫に寄生するウ
イルスや細菌, 寄生虫に寄生する原虫など, その相互作用はき わめて複雑系なのである。伝統的な人や家畜を対象とした下流 からのアプローチでは解決できない。発想を変え環境, 野生生 物や野生動物の生態と病原体の振る舞いを知る上流からのアプ ローチが重要である（図2）。

\section{4. 例えば， ウイルスについて分かっていることは？}

実際, 我々はウイルスについてどのくらい知っているのであ ろうか? 例えば, 地球上にいったいどれくらいの数のウイル スがいるのか? 正確な数字は分からない。次世代シークエン サーによるメタゲノム解析が進めば，おおよその姿は見えてく るかも知れない。文献によれば，国際ウイルス学会は人や動植 物，原虫，細菌などに感染するウイルスとして，約 5,400 種 を確認している。『感染症とは?』の項目で述べたように, 我々 が解いてきたものは特殊解である。したがって, 分かっている ウイルスも, そのほとんどが陸上の生物に感染するものであり, 人や家畜に感染するものが最も多い。それ以外の生物でも産業 に関連する家禽, 䖯, ミツバチ, あるいは魚貝類, 植物では, 果物，野菜などに感染するウイルスなどである。いずれも人の 生活に直接関わりのある生物種に感染するウイルスに限られて いる。今知られている，175万種といわれる生物種がそれぞれ， 平均 20 種類のウイルスに感染するとしても，3,500 万種とい う数になる。重複を除いたとしても膨大な数である。

しかし, ウイルスの生息域は, 我々の生息域である陸上だけ ではない。30 億年の歴史をもつといわれるウイルスは，地球 の多くを占める海にも膨大に存在する。このことは最近, 明ら かになってきた。これらのウイルスは，ほとんどが藻類のウイ 


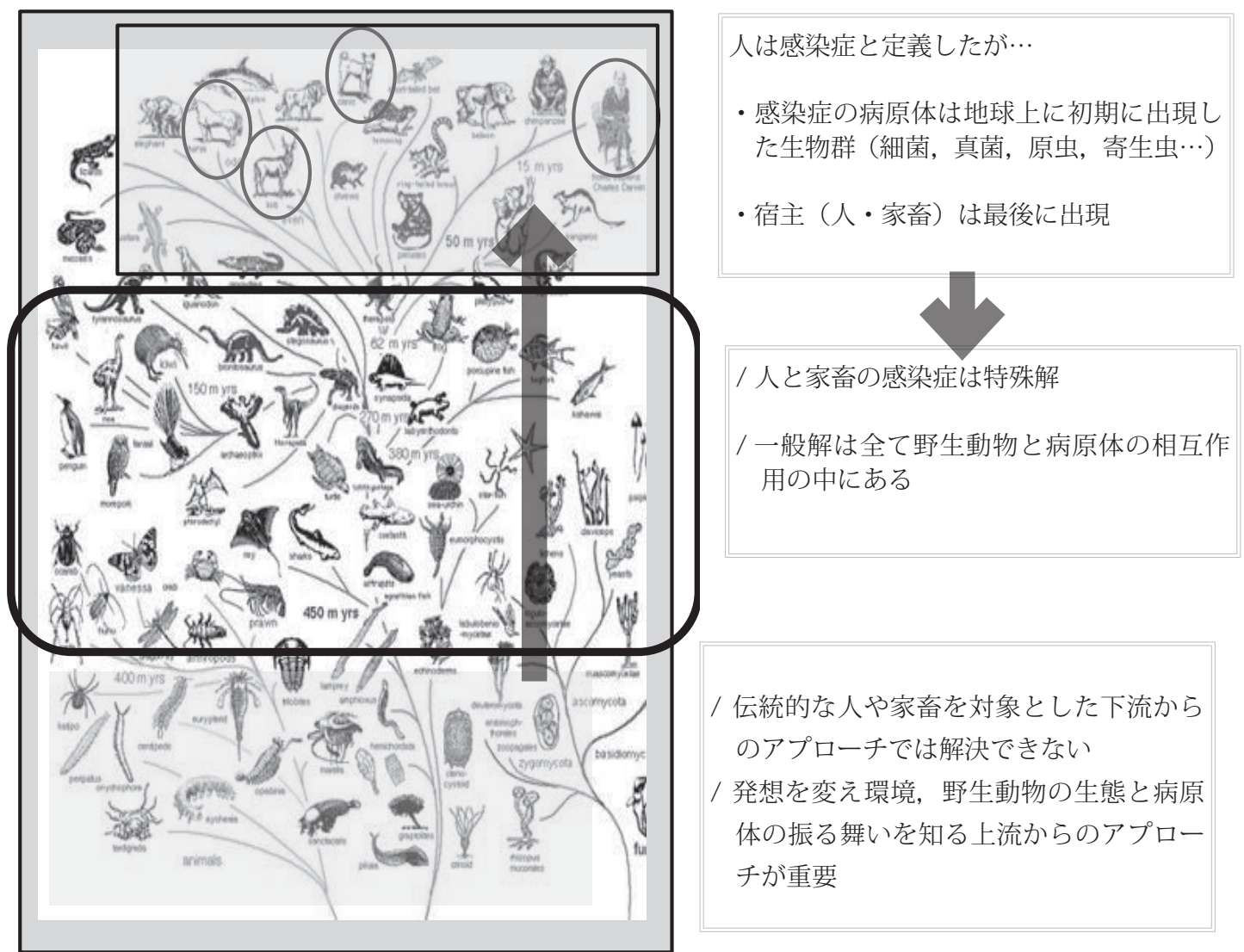

図 2 原始生命群と高等動物の相互作用としての感染症 系統樹から見た病原体と宿主（図左），感染症のアプローチ（図右）

ルスで，通常のサイズの藻類から顕微鏡サイズの微細藻類に感 染している。藻類は分かっているだけでも 3 万〜 4 万種あり, 分類学的にも曖昧な点が多い。その定義も, 「藻類とは, 酸素 を発生する光合成を行う生物の中からコケ植物, シダ植物およ び種子植物を除いた残りの全て」というものである。さらに渦 鞭毛藻やミドリムシ藻の中には葉緑体をもたない種がいて, こ れらの「藻類」は光合成を行わずに慨を捕食することによって 生きている。多細胞のもの, 単細胞のもの, 有核のもの, 核を もたない原核生物に属するものなど，きわめて多様である。

このような生物群に感染する海水中のウイルスは, 少なく とも $1 \mathrm{ml}$ 中に, 深海で百万個, 沿岸で 1 億個, 世界の海全体 で $10^{31}$ 個といわれている。海のウイルス粒子全てをつなぐと, その長さは銀河系の直径の約 100 倍, 1,000 万光年の長さに なるといわれる。炭素量ではシロナガスクジラ 7,500 万頭分 に匹敵する（参考文献 $1 ， 2 ） 。$ 膨大な種数と存在量である。

\section{5. 日本における動物由来感染症統御 : 輸入動物のリスク評価}

人獣共通感染症対策として, 近年, 国際機関の専門家委員会 で用いられる分析手法にリスク分析法がある。具体的には科学 的・定量的なリスク評価に基づき, 行政が費用対効果などを検 討し，基準や措置・対策を作成する。市民への説明責任を果た すために人々への説明と同意を求め, より効率のよい防御シス テムを確立する方法である。また, 感染症のリスクはダイナミッ クに変動し, 感染症ごとにリスクの高さにも差がある。こう したリスクに応じた管理を行うためには, リスク管理も all or nothing といった単純な法的対応でなく, リスクのレベルに応 じたきめ細かい管理方法をとる必要がある。そのためには定量 的なリスク評価が必要である。

感染症法を制定し（1998 年），その後，動物由来感染症の リスク回避方法を検討した（1993 年）。最もリスクが高いシ ナリオとしては輸入野生動物に由来する感染症の侵入である ということになった。このリスク評価とリスク管理を行うため 
吉川泰弘

に, 動物由来感染症に関する世界の地域別発生情報の整理，国 別輸入動物数のデータ入手, 疾病の重要度評価などのデータを 作成し, 厚労省の動物由来感染症検討班で初めてリスク分析を 行った（図 3 上図）。具体的には, ステップ 1 では, 世界各地・ 各国のズーノーシスの発生状況を, WHO, OIE, GIDEON など のデータに基づき入力し, カテゴリー化した。高污染国は当該 疾病の発生が最近 5 年間連続発生あるいは年間 10 人以上の発 症, 中等度污染国は最近 5 年間で 3 回以上の流行, あるいは 年間 9 人以下 1 人以上発症, 低污染国は 5 年間に流行があっ た, 污染の疑われる国は過去 10 年間に発生が疑われる, それ 以外は清浄国とした。ステップ2では, マトリックスを組んだ。 縦に污染国のカテゴリー（高污染国から清浄国）をとり, 横軸 に輸入動物ごとの動物数を分類した。すなわち，100 頭以下， 100 から千頭, 千頭から 1 万頭, 1 万頭以上。このマトリッ クスで非常に危険から, 危険, 中等度, やや少ない, 少ない, 問題なしに分類した（図３下図）。ステップ３では感染症の重
要度を, 動物種と感染症の組合せで, 星 1 つから星 5 つに分 類した（図 4 上図）。ステップ 4 （最終評価）では, 再びマト リックスを組み, 縦軸に非常に危険から問題なしを, 横軸に星 1 つから星 5 つをおき，0 から 10 点とした（図 4 下図）。そ のうえで地域, 動物, 疾病の組合せ点を, 総得点と平均值で示 した。

リスク評価結果により翼手目とマストミス，プレーリードッ グ, ハクビシンなどは全面輸入禁止となった。サル類に関して は, アフリカ産のサル類は輸入禁止, それ以外の地域から輸入 されるサル類は, 輸出前検疫, 輸入後検疫を義務づけた。また 全ての輸入動物（およびげっ歯類の死体輸入）について厚生労 働省への届出義務, げっ歯類繁殖施設の証明書, 輸出国政府発 行の健康証明書の添付などが義務づけられた。

さらに獣医師の責務の拡大とともに, 政・省令により届出 (犬 のエキノコックス, サル類の赤痢・後にサル類の結核が追加, 西ナイル熱の鳥類, 高病原性鳥インフルエンザ H5N1 で, 家

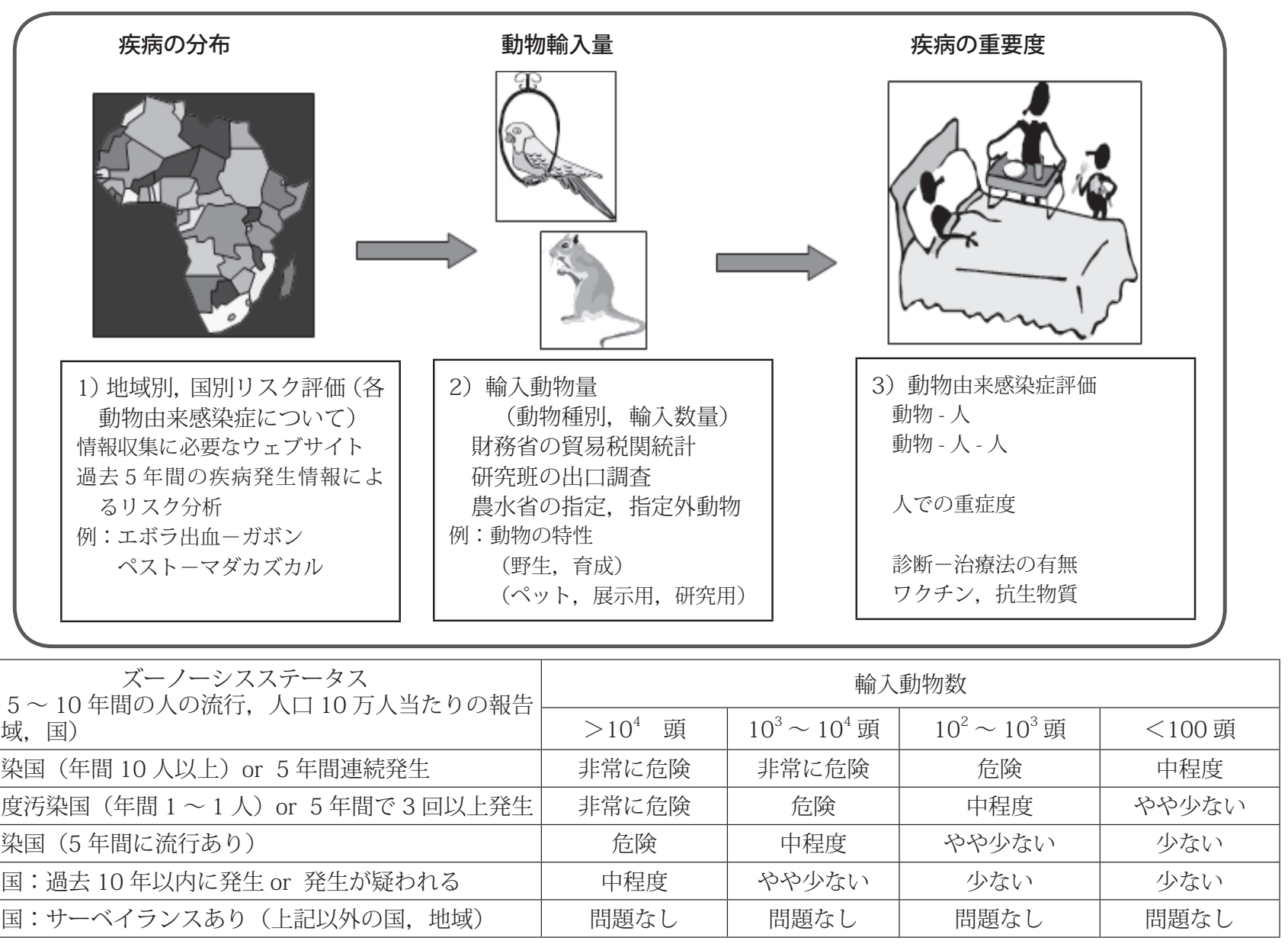

図 3 輸入動物によるズーノーシス侵入のリスク評価方法

上図はリスク評価法のフローチャート，下図はリスク国と輸入動物数のマトリックス 
動物由来感染症

\begin{tabular}{|c|c|c|c|c|c|}
\hline & \multicolumn{5}{|c|}{ 重要度 } \\
\hline & $5 \lesssim$ & 4 公 & $3 \varkappa$ & $2 \lesssim$ & $1 \grave{s}$ \\
\hline 霊長類 & $\begin{array}{l}\text { エボラ出血 } \\
\text { 熱, マールブ } \\
\text { ルグ病 }\end{array}$ & $\begin{array}{l}\text { B ウイルス病, 黄 } \\
\text { 熱 }\end{array}$ & $\begin{array}{l}\text { 赤痢, アメーバ赤痢, } \\
\text { サル痘, 結核, デング } \\
\text { 熱 }\end{array}$ & & $\begin{array}{l}\text { 粪線虫症, ジアルジア } \\
\text { 症, エルシニア症, カ } \\
\text { ンピロバクター症 }\end{array}$ \\
\hline $\begin{array}{l}\text { げっ歯類・ベクター（鼠 } \\
\text { 属, 節足動物など侵入 } \\
\text { 動物を含む) }\end{array}$ & 狂犬病 & $\begin{array}{l}\text { ラッサ熱, ペスト, } \\
\text { HPS, HFRS, ク } \\
\text { リミアコンゴ出血 } \\
\text { 熱, 黄熱, デング } \\
\text { 出血熱 }\end{array}$ & $\begin{array}{l}\text { 日本脳炎, LCM, Q熱, } \\
\text { トリパノソーマ病, ラ } \\
\text { イム病, マラリア, リ } \\
\text { フトバレー熱, サルモ } \\
\text { ネラ症, デング熱, ツ } \\
\text { ツガムシ病, 日本紅斑 } \\
\text { 熱, レプトスピラ症 }\end{array}$ & $\begin{array}{l}\text { 発疹熱, 鼠咬症, } \\
\text { 回帰熱, 発疹チフ } \\
\text { ス, リーシュマニ } \\
\text { ア症, 広東住血線 } \\
\text { 虫症 }\end{array}$ & $\begin{array}{l}\text { エルシニア症, カンピ } \\
\text { ロバクター症 }\end{array}$ \\
\hline 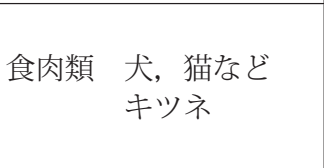 & 狂犬病 & & $\begin{array}{l}\text { レプトスピラ症, ライ } \\
\text { ム病, 野兔病, エキノ } \\
\text { コックスス症, トリパノ } \\
\text { ソーマ病 }\end{array}$ & $\begin{array}{l}\text { 仮性結核, トキソ } \\
\text { プラズマ症, リー } \\
\text { シュマニア症 }\end{array}$ & $\begin{array}{l}\text { トキソカラ症, パスッ } \\
\text { レラ症, アライグマ回 } \\
\text { 虫症, ジアルジア症, } \\
\text { 糞線虫症 }\end{array}$ \\
\hline 翼手類 コウモリ & 狂犬病 & $\begin{array}{l}\text { リッサ, ヘンドラ, } \\
\text { ニパウイルス感染 } \\
\text { 症 }\end{array}$ & & & \\
\hline 鳥類 & & $\begin{array}{l}\text { 西ナイル熱, 高病 } \\
\text { 原性鳥インフルエ } \\
\text { ンザウイルス感染 } \\
\text { 症, クリミアコン } \\
\text { ゴ出血熱 }\end{array}$ & オウム病, ライム病 & & クリプトコックス病 \\
\hline 両生類・爬虫類 & & & サルモネラ症 & & \\
\hline 家畜 & 狂犬病 & $\begin{array}{l}\text { 炭疽, クリミアコ } \\
\text { ンゴ出血熱 }\end{array}$ & $\begin{array}{l}\text { リフトバレ一熱, 結核, } \\
\text { O157 腸管出血性大腸 } \\
\text { 菌症, リステリア症, } \\
\text { サルモネラ症, エキノ } \\
\text { コックス症，Q熱，レ } \\
\text { プトスピラ症，ライム } \\
\text { 病 }\end{array}$ & $\begin{array}{l}\text { 鼻疽, ブルセラ症, } \\
\text { トキソプラズマ症 }\end{array}$ & $\begin{array}{l}\text { クリプトスポリジウム } \\
\text { 症, ジアルジア症, 肝蛭, } \\
\text { エルシニア症, 類丹毒, } \\
\text { カンピロバクター症 }\end{array}$ \\
\hline
\end{tabular}

\begin{tabular}{|l|c|c|c|c|c|}
\hline \multirow{2}{*}{ 侵入リスク } & \multicolumn{5}{|c|}{ 重要度 } \\
\cline { 2 - 6 } & 5 方 & 4 方 & 3 方 & 2 坊 & 1 方 \\
\hline 非常に危険 & 10 & 9 & 7 & 5 & 3 \\
\hline 危険 & 9 & 7 & 5 & 3 & 2 \\
\hline 中等度 & 7 & 5 & 3 & 2 & 1 \\
\hline やや少ない & 5 & 3 & 2 & 1 & 0 \\
\hline 少ない & 3 & 2 & 1 & 0 & 0 \\
\hline 問題なし & 0 & 0 & 0 & 0 & 0 \\
\hline
\end{tabular}

図 4 輸入動物リスク評価のステップ 3 とステップ 4

上図は動物別ズーノーシスの重要度, 下図は侵入リスク（リスク国と輸入動物数の組合せ）と感染症重要度をマトリックスに組んだ リスクポイント

禽以外の鳥の感染が届出義務となった）の義務, 感染症情報提 供（西ナイル熱の蚊, 展示施設でのオウム病など）が追加され た。また動物由来感染症のほとんどが含まれる 4 類感染症の 積極疫学, 必要に応じて動物の調査, 対物措置もとることがで きるようになった。
この新しいリスク管理方法は, 従来のように単純に動物検 疫種数を増加させるものではなく, 輸入禁止動物種の追加, 輸入検疫, 係留措置, 国内の野生動物, 飼育動物の対策を強 化し（リスク回避 : risk management）, 感染症発生時の動物 調査, 措置の強化を盛り込むことになった（危機管理：crisis 
吉川泰弘

management）。特に輸入動物の届出制度と健康証明書の添付, 特定の病原体に関するフリーの証明書添付の要求は, これまで 野放しであった輸入野生動物を事実上禁止するものであり，検 疫に代わってリスクを回避する有効な措置となっている。

事実，法律実施後の追跡調查では，90\%以上の輸入動物は 野生動物でなくなった。また輸出国も東南アジア, 中東, アフ リカから,アメリカや欧州に変わった。これまでのような, 動 物の輸入禁止か完全フリーかという単純図式でなくリスク評価 に応じた管理措置をとる方針を選んだという点では，画期的な 対応となった。国際的にみても，このようなリスク評価に基づ く野生動物の輸入制度はカナダで行われただけのようである。 現在 OIE の野生動物疾病ワーキンググループで検討を始めて いる。

\section{6. 日本における動物由来感染症統御 : 動物由来感染症の序列化}

上述したように，輸入動物に関する半定量的リスク評価法の 開発，リスク評価法に基づく地域別，動物種別の総合リスク評 価, リスク評価に基づく輸入動物の新しいリスク管理法の作成 および法律の改正（2005 年）により, 最も危険と考えられた 輸入野生動物に由来するリスクは回避できた。輸入業者, 動物
関連業者の方々には多大の負担を強いたが，これによりニアミ スで危機を回避できた例がいくつかあった。

そのあと, 人獣共通感染症の新しい統御法に関して, 総論的 なアプローチの開発に努力してきた。個々の感染症でなく, ズー ノーシス全体を統御する方法として, 以下のステップをアプ ローチ方法として考えた。(1)スクシナリオの作成とリスク評 価：120 種類を超す, ズーノーシスの個々の感染症について リスクシナリオを作成する。この際サーベイランス・データが キーポイントとなる。作成したシナリオをもとに, 統一的, 一 貫性をもったリスク評価法を考案する。感染症に関連する因 子の重み付けを，定量化するために AHP （analytic hierarchy process）のような, 一対比較, 階層化意志決定法などを利用 する。(2)感染症の序列化と標的感染症の重要管理点の明確化 : 上記の統一的評価法を用いて感染症の序列化（prioritization） を行う。序列化を行うには, 科学性, 中立性, 一貫性, 透明性 を確保し，ステークホルダーに説明と同意を得ることが必要で ある。序列化により, 標的とすべき感染症が絞り达まれたら, 標的感染症の重要管理点：critical control point（CCP）を明確 化する必要がある。個々の感染症のリスクシナリオとそれを支 える科学的なサーベイランス・データ（標的サーベイランスと 一般的サーベイランス・データなど）が CCP の決定にはきわ

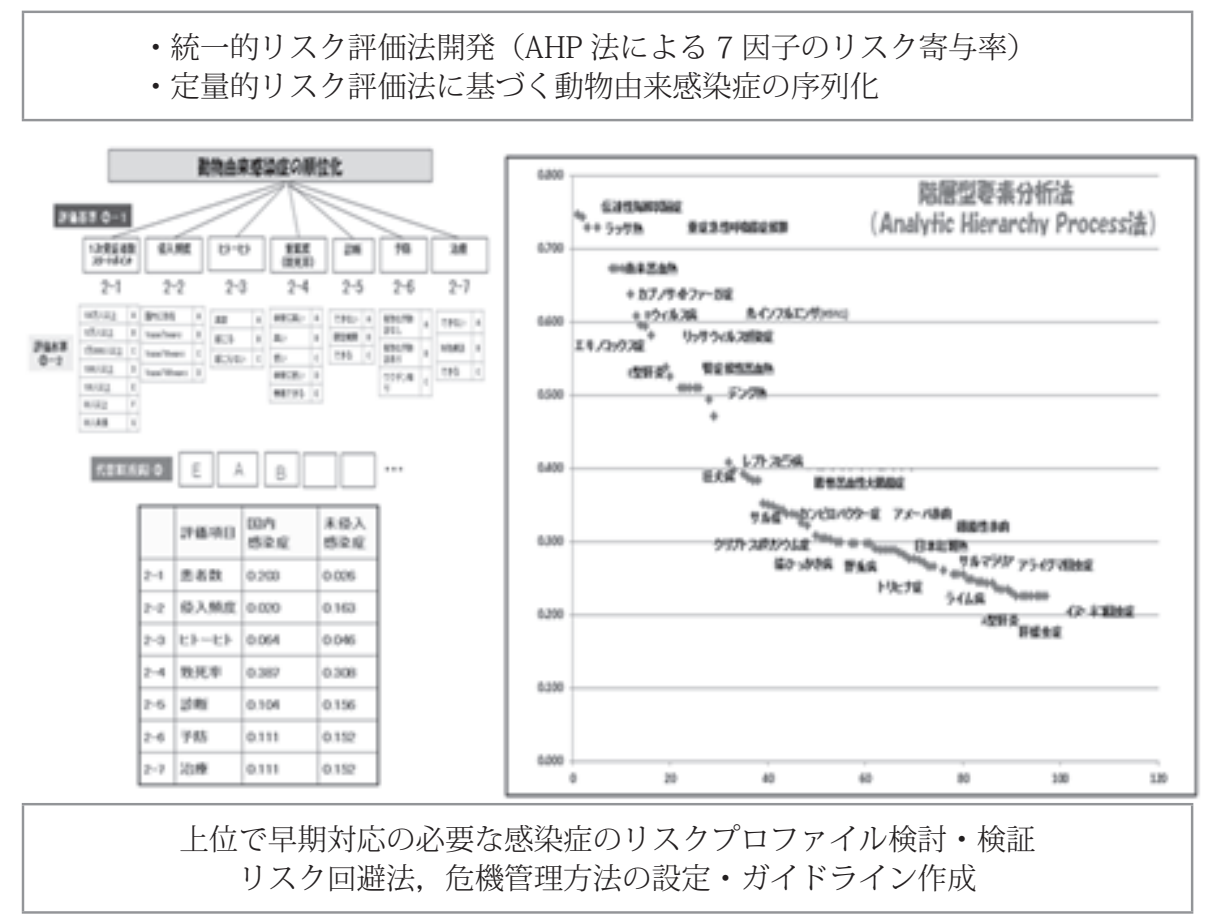

図 5 ズーノーシスの統一的リスク評価方法と序列化

図左はAHP 法によるズーノーシスの評価と 7 つ因子の重み付け。図右は, AHP 法を用いたズーノシスの序列化（縦軸はポイント， 横軸は順位）。 
めて重要である。重要管理点の決定には, リスク管理側のコス ト・ベネフィット計算, リスクのトレードオフなどの検討も必 要となる。(3)実施と検証：リスク管理措置が決まれば, 感染症 統御の実施, 実施後の統御の有効性検証が必要になる。適切な 対応により, リスクが減少し, 序列（重要度）が下がれば, 別 のプライオリティーの高い感染症の統御に移る。この繰り返し になる。

感染症の因子の重み付けに用いたAHP 法は, 1971 年に Thomas L. Saaty 博士（ピッツバーグ大学）が提唱した方法で ある。多基準の選択問題があるとき, 目標・評価基準・代替案 の階層構造に整理したうえで, 各階層における要素同士の相対 的な重要度を導き出し，それらを総合することで最適な評価・ 選択を図るという手法である。この方法は, 各因子の重要度を 項目全体に対して数值化するのが困難であっても, 2 つの項目 間での重要性の比較判断はしやすく, データの入手が容易であ る点を利用している。2 項目の比較の程度を主観的に判断した うえで, 客観的な統計理論を用いて加工することにより, 主観 と客観を統合することができる。

この方法を使うと国内にある感染症では各因子の重み付け は, 致死率が 0.387, 患者数が 0.203, 予防法の有無が 0.111, 治療法の有無が 0.111 , 診断の可否が 0.104 , 人 - 人感染が 0.064 , 侵入頻度が 0.020 となった。他方海外にある未侵入 の感染症では, 致死率が 0.308 , 侵入頻度が 0.163 , 診断の可 否が 0.156, 予防法の有無が 0.152, 治療法の有無が 0.152,
人 - 人感染が 0.046 , 患者数が 0.026 となった。上位で, これ までに有効な対策がとられていない感染症で, 早期に対応の必 要なものから, 順次, 統御法を見つけ実行していく。今回対 象となった感染症は, B ウイルス病, エキノコックス症, 高病 原性鳥インフルエンザ, リッサウイルス感染症, カプノサイト ファーガ症であった。

\section{7. 野生動物由来感染症の統御の課題}

野生動物由来感染症および野生動物疾病の統御に最も重要 な要素の 1 つはサーベイランスである。我が国では縦割り行 政のために統合的アプローチができない。マンハッタン原則の 中でいわれていたように, この課題の取組みには学問分野を超 え, 行政 (省庁) の壁を超えた統合的アプローチが必要である。 例えば現在, 高病原性鳥インフルエンザの監視で収集したサン プルは他の調査には使えない。

さらに，サーベイランスの実行部隊となるべき現場の人事権 は, 国ではなく地方自治体の長に委託されている。すなわち「現 場（家畜保健衛生所, 食肉処理場, 保健所, 猟友会など）は国 でなく県知事，市町村の支配下にある。したがって，国が方向 を決めたとしても, 実際に地方自治体が連携して動くことは少 なく，また得られたデータを共有するシステムもない。

第 3 には, 野生動物のサーベイランス理論がない。調査結 果は分断されたケースレポートとして残されるのがほとんど

1. 縦割り行政のため統合的アプローチができない

例：HPAI で収集したサンプルは他の調査に使えない

2. 現場（家保，食肉処理場，保健所，粆友会）は国ではなく県知事，市町村の支配下

3. 野生動物のサーベイランス理論がない（分断されたケースレポート）

4. 司令塔（戦略, 情報収集・分析・発信・保管, 資源一金・人・物一供給）の欠如

5. 法整備ができていない

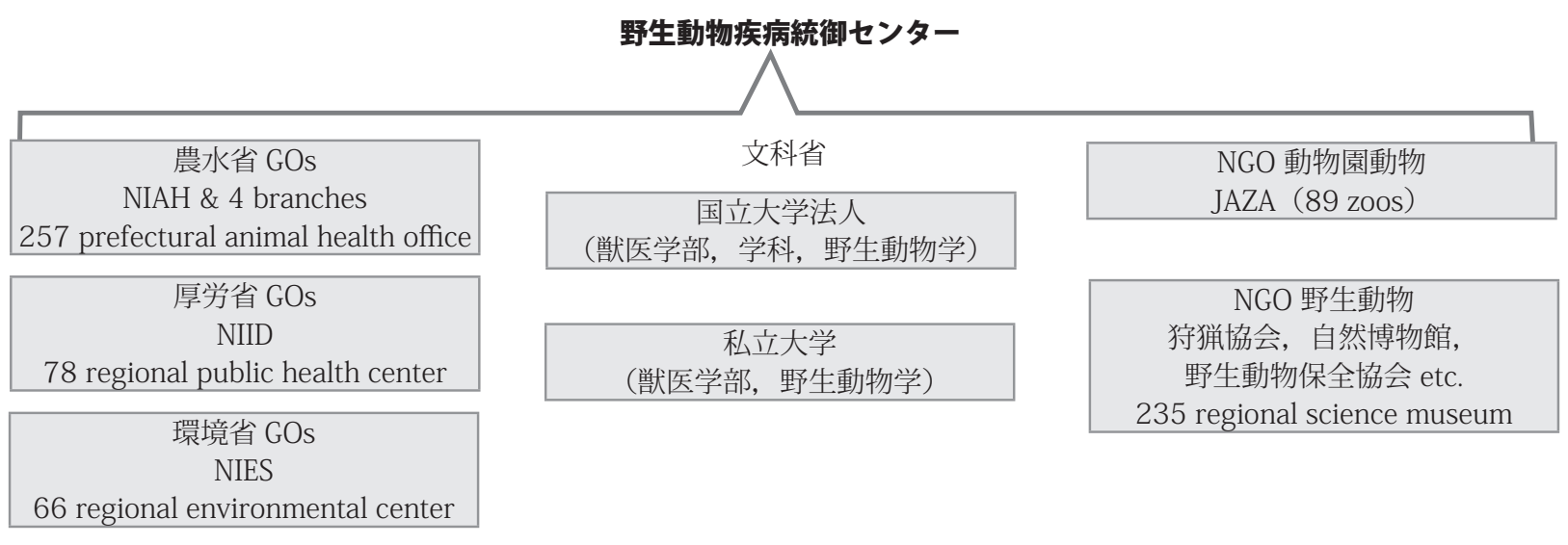

図6 野生動物疾病の統御に関する課題

野生動物疾病の統御体制を確立するための 5 つの課題（上段）と司令塔の構築図（下図） 
で, 網羅的, 統合的にデータを収集することは不可能である。 学会要旨集, 研究会発表データ, 県市町村の調査報告, 年報, 紀要などを必要とする各自が集めるしかない。さらに, 残され ているデータも, 一時的に収集されたもので, 疫学的なデザイ ンや戦略に基づくデータは少なく, そうした解析も行われてい ない。

我が国では野生動物疾病に関する司令塔（戦略，情報収集・ 分析・発信・保管，資源の供給一金・人・物）が久如している。 厚労省, 農水省, 文科省, 環境省が少しずつこの課題に関与し ているが，諸外国にあるような中心的なナショナルセンターと なる機関ができていない。大学の野生動物研究室, 各省庁関連 機関の一室, あるいは地方の機関の一部などが, それぞれバラ バラに活動している。

最後の問題は, この課題に関する法整備ができていない点で ある。動物の愛護と管理に関する法律, 感染症法, 家畜伝染病 予防法, 鳥獣の保護抢よび狩編の適正化に関する法律, 生物多 様性地域連携促進法, 自然環境保全法, 文化財保護法 (天然記 念物），絶滅の抢それのある野生動植物の種の保存に関する法 律など, 様々な法律が野生動物と関連している。個々の法律の 目指すところと, 野生動物疾病制御の両立を図るためにも, 新 しい法律の整備が必要である。

\section{8.おわりに}

ズーノーシスのみならず, 後の演者が紹介するように, 野 生動物疾病の制御は, 多くの問題点をもちつつ, 少しずつ前進 している。本学会の自由集会, シンポジウムなどでも, すでに 何度も取り上げられている。OIE の提示した獣医学のコアカリ キュラムにも, また, 新しい我が国の獣医学教育カリキュラム にも野生動物学が独立して組み込まれている。本学会が責任を もって次世代を担うこの分野の研究者を育てていかなければな らない。

\section{要 約}

国連の機関である国際保健機関（WHO），国連の食糧農業機 関 (FAO)，やユニセフ (UNICEF) および国際獣疫事務局 (OIE),
世界銀行（WB）などが一堂に会して議論した結果が 2004 年 に野生動物保護協会（WCS: Wildlife Conservation Society）か らマンハッタン原則として提示された。この原則のキーワー ドが「One World, One Health」である。この原則では, 以下 のような認識を基本概念においている。すなわち「近年のウ エストナイル熱, エボラ出血熱, SARS, サル痘, BSE, 鳥イン フルエンザの流行は人と動物の健康が密接に関連していること を想起させる。したがって, 人, 家畜, 野生動物の健康（One Health）を追求する統合的アプローチが必要である。また，種 の絶滅, 生息域の劣化, 污染, 外来種の侵入, 温暖化などは地 球の原生自然を根本から変えつつある。新興・再興感染症は人 （食糧供給，経済活動を含む）のみならず世界の基底を支える 生物多様性に扔いても脅威となる。我々は 1 つの世界に生き ている（One World）。21 世紀に感染症を克服するには，より 広範な環境の保全活動と同時に, 疾病の予防, サーベイランス, モニタリング, 管理などに関して分野を超え, 融合したアプロー チが必要である」と述べている。WCS は, 具体的な 12 項目 のアクションプランを提示している。このシンポジウムでは, 野生動物に由来するズーノーシス, 野生動物と家畜の間で行き 来する感染症, 野生動物自身の感染症について議論する。我々 は医獣連携を感染症統御の基本と認識している。国際的には, 種々のプロジェクトが One World One Health, One Medicine, Conservation Medicine あるいは One Health Initiative という名 前で進行している。名称は異なるが基本的コンセプトは類似し ている。本シンポジウムでは国内におけるこのような概念の具 現化を図るために進められている研究の実例を紹介する。また， 海外における中核研究所, 中核機関 (OIE) の戦略などを紹介し, 日本におけるこれからの展望について議論を行う考えである。 キーワード:ズーノーシス, マンハッタン原則，1つの世界・ 1 つの健康, リスク評価, リスク管理

\section{引用文献}

1. 山内一也. 2006. NHKライブラリー地球村で共存するウイルスと人類, 日本放送出版協会, 東京.

2. Suttle,C.A. 2005. Viruses in the sea. Nature 437: 356-361. 